\title{
Basic science: (April 2008)
}

1. Ahmad R, Raina D, Meyer C, Kufe D. Triterpenoid CDDO-methyl ester inhibits the janus-activated kinase-1 (JAK1) $\rightarrow$ Signal transducer and activator of transcription-3 (STAT3) pathway by direct inhibition of JAK1 and STAT3. Cancer Res 2008; 68: 2920-2926.

2. Antoniou AC, Cunningham AP, Peto J, Evans DG, Lalloo F, Narod SA, Risch HA, Eyfjord JE, Hopper JL, Southey MC, Olsson H, Johannsson O, Borg A, Passini B, Radice P, Manoukian $\mathrm{S}$, Eccles DM, Tang N, Olah E, Anton-Culver H, Warner E, Lubinski J, Gronwald J, Gorski B, Tryggvadottir L, Syrjakoski K, Kallioniemi OP, Eerola H, Nevanlinna H, Pharoah PDP, Easton DF. The BOADICEA model of genetic susceptibility to breast and ovarian cancers: updates and extensions. Br J Cancer 2008; 98: 1457-1466.

3. Antoniou AC, Spurdle AB, Sinilnikova OM, Healey S, Pooley KA, Schmutzler RK, Versmold $B$, Engel C, Meindl A, Arnold N, Hofmann W, Sutter C, Niederacher D, Deissler H, Caldes T, Kampjarvi K, Nevanlinna H, Simard J, Beesley J, Chen XQ, Neuhausen SL, Rebbeck TR, Wagner T, Lynch HT, Isaacs C, Weitzel J, Ganz PA, Daly MB, Tomlinson G, Olopade OI, Bium JL, Couch FJ, Peterlongo P, Manoukian S, Barile M, Radice P, Szabo Cl, Pereira LHM, Greene MH, Rennert G, Leibkowicz F, Barnett-Griness O, Andrulis IL, Ozcelik H, Gerdes AM, Caligo MA, Laitman Y, Kaufman B, Milgrom R, Friedman E, Domchek $\mathrm{SM}$, Nathanson KL, Osorio A, Llort G, Milne RL, Benitez J, Hamann U, Hogervorst FBL, Manders $P$, Ligtenberg MJL, van den Ouweland AMW, Peock S, Cook M, Platte R, Evans DG, Eeles R, Pichert G, Chu C, Eccles D, Davidson R, Douglas F, Godwin AK, Barjhoux L, Mazoyer S, Sobol H, Bourdon V, Eisinger F, Chompret A, Capoulade C, Paillerets BBD, Lenoir GM, Gauthier-Villars M, Houdayer C, Stoppa-Lyonnet D, Easton DF. Common breast cancer-predisposition alleles are associated with breast cancer risk in BRCA1 and BRCA2 mutation carriers. Am J Hum Genet 2008; 82: 937-948.
4. Bennett HL, Brummer T, Jeanes A, Yap AS, Daly RJ. Gab2 and Src co-operate in human mammary epithelial cells to promote growth factor independence and disruption of acinar morphogenesis. Oncogene 2008; 27: 2693-2704.

5. Caldon CE, Swarbrick A, Lee CSL, Sutherland RL, Musgrove EA. The helix-loop-helix protein Id1 requires cyclin D1 to promote the proliferation of mammary epithelial cell acini. Cancer Res 2008; 68: 3026-3036.

6. Chan SW, Lim CJ, Guo K, Ng CP, Lee I, Hunziker W, Zeng Q, Hong WJ. A role for TAZ in migration, invasion, and tumorigenesis of breast cancer cells. Cancer Res 2008; 68: 2592-2598.

7. Crawford NPS, Alsarraj J, Lukes L, Walker RC, Officewala JS, Yang HH, Lee MP, Ozato K, Hunter KW. Bromodomain 4 activation predicts breast cancer survival. Proc Natl Acad Sci USA 2008; 105: 6380-6385.

8. Descotes F, Riche B, Saez S, De Laroche G, Datchary J, Roy P, Andre J, Bobin JY. Plasminogen activator inhibitor type 1 is the most significant of the usual tissue prognostic factors in node-negative breast ductal adenocarcinoma independent of urokinase-type plasminogen activator. Clin Breast Cancer 2008; 8: 168-177.

9. Dhakal HP, Naume B, Synnestvedt M, Borgen E, Kaaresen R, Schlichting E, Wiedswang G, Bassarova A, Giercksky KE, Nesland JM. Vascularization in primary breast carcinomas: its prognostic significance and relationship with tumor cell dissemination. Clin Cancer Res 2008; 14: 2341-2350.

10. Diorio C, Brisson J, Berube S, Pollak M. Genetic polymorphisms involved in insulin-like growth factor (IGF) pathway in relation to mammographic breast density and IGF levels. Cancer Epidemiol Biomarkers Prev 2008; 17: 880-888.

11. Gilbert JA, Goetz MP, Reynolds CA, Ingle JN, Giordano KF, Suman VJ, Blair HE, Jenkins RB, Lingle WL, Reinholz MM, Adiei AA, Ames MM. Molecular analysis of metaplastic breast carcinoma: high EGFR copy number via aneusomy. Mol Cancer Ther 2008; 7: 944-951. 
12. Golden T, Aragon LV, Rutland B, Tucker JA, Shevde LA, Samant RS, Zhou G, Amable L, Skarra D, Honkanen RE. Elevated levels of Ser/Thr protein phosphatase 5 (PP5) in human breast cancer. Biochim Biophys Acta-Mol Basis Dis 2008; 1782: 259-270.

13. Horwitzt KB, Dye WW, Harrell JC, Kabos P, Sartorius CA. Rare steroid receptor-negative basal-like tumorigenic cells in luminal subtype human breast cancer xenografts. Proc Natl Acad Sci USA 2008; 105: 5774-5779.

14. Kendall A, Anderson H, Dunbier AK, Mackay A, Dexter T, Urruticoechea A, Harper-Wynne C, Dowsett M. Impact of estrogen deprivation on gene expression profiles of normal postmenopausal breast tissue in vivo. Cancer Epidemiol Biomarkers Prev 17:855-863.

15. Ladoire S, Arnould L, Apetoh L, Coudert B, Martin F, Chauffert B, Fumoleau P, Ghiringhelli F. Pathologic complete response to neoadjuvant chemotherapy of breast carcinoma is associated with the disappearance of tumorinfiltrating Foxp3(+) regulatory $\mathrm{T}$ cells. Clin Cancer Res 2008; 14: 2413-2420.

16. Li Y, Zhang Y, Hill J, Kim HT, Shen Q, Bissonnette RP, Lamph WW, Brown PH. The rexinoid, bexarotene, prevents the development of premalignant lesions in MMTV-erbB2 mice. Br J Cancer 2008; 98: 1380-1388.

17. Lubet RA, Szabo E, Christov K, Bode AM, Ericson ME, Steele VE, Juliana MM, Grubbs CJ. Effects of gefitinib (Iressa) on mammary cancers: preventive studies with varied dosages, combinations with vorozole or targretin, and biomarker changes. Mol Cancer Ther 2008; 7: 972-979.

18. Newcomb PA, Egan KM, Trentham-Dietz A, Titus-Ernstoff L, Baron JA, Hampton JM, Stampfer MJ, Willett WC. Prediagnostic use of hormone therapy and mortality after breast cancer. Cancer Epidemiol Biomarkers Prev 2008; 17: 864-871.

19. Pan MR, Hou MF, Chang HC, Hung WC. Cyclooxygenase-2 up-regulates CCR7 via EP2/EP4 receptor signaling pathways to enhance lymphatic invasion of breast cancer cells. J Biol Chem 2008; 283: 11155-11163.

20. Sarkar C, Chakroborty D, Chowdhury UR, Dasgupta PS, Basu S. Dopamine increases the efficacy of anticancer drugs in breast and colon cancer preclinical models. Clin Cancer Res 2008; 14: 2502-2510.

21. Serrati S, Margheri F, Fibbi G, Cara GD, Minafra L, Pucci-Minafra I, Liotta F, Annunziato F, Pucci M, Del Rosso M. Endothelial cells and normal breast epithelial cells enhance invasion of breast carcinoma cells by CXCR-4-dependent up-regulation of urokinase-type plasminogen activator receptor (UPAR, CD87) expression. $J$ Pathol 2008; 214: 545-554.

22. Shai A, Pitot HC, Lambert PF. p53 loss synergizes with estrogen and papillomaviral oncogenes to induce cervical and breast cancers. Cancer Res 2008; 68: 2622-2631.

23. Shakya R, Szabolcs M, McCarthy E, Ospina E, Basso K, Nandula S, Murty V, Baer R, Ludwig T. The basal-like mammary carcinomas induced by Brca1 or Bard1 inactivation implicate the BRCA1/BARD1 heterodimer in tumor suppression. Proc Natl Acad Sci USA 2008; 105: 7040-7045.

24. Sun H, Berquin IM, Owens RT, O'Flaherty JT, Edwards IJ. Peroxisome proliferator-activated receptor $\gamma$-mediated up-regulation of syndecan- 1 by $n-3$ fatty acids promotes apoptosis of human breast cancer cells. Cancer Res 2008; 68: 2912-2919.

25. Weng SC, Kashida Y, Kulp SK, Wang D, Brueggemeier RW, Shapiro CL, Chen CS. Sensitizing estrogen receptor-negative breast cancer cells to tamoxifen with OSU-03012, a novel celecoxib-derived phosphoinositidedependent protein kinase-1/Akt signaling inhibitor. Mol Cancer Ther 2008; 7: 800-808.

\author{
Prepared by \\ $R$ Sutherland \\ Cancer Research Program \\ Garvan Institute of Medical Research \\ Darlinghurst, NSW, Australia
}

